Jurnal Pendidikan Matematika : Judika Education

Volume 2, Nomor 2, Juli-Desember 2019

e-ISSN : 2614-6088

p-ISSN : 2620-732X

DOI : https://doi.org/10.31539/judika.v2i2.863

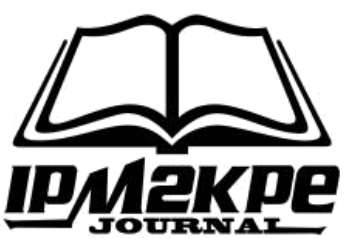

\title{
PENGEMBANGAN LEMBAR KERJA SISWA (LKS) \\ MENGGUNAKAN CONTEXTUAL TEACHING AND \\ LEARNING (CTL) BERBASIS KOTA LUBUKLINGGAU
}

\author{
Rani Refianti ${ }^{1}$, Marisa $Z^{2}$, Novianti Mandasari ${ }^{3}$ \\ STKIP-PGRI Lubukl inggau ${ }^{1,2,3}$ \\ ranirefianti834@gmail.com ${ }^{1}$
}

\begin{abstract}
ABSTRAK
Tujuan penelitian ini adalah untuk mengembangkan lembar kerja siswa (LKS) mengggunakan Contextual Teaching and Learning (CTL) berbasis kota Lubuklinggau pada materi himpunan di kelas VII sesuai kurikulum 2013 dan mengetahui kualitas LKS yang dikembangkan dari aspek kevalidan, kepraktisan dan efek potensial penggunaan LKS. Metode penelitian yang digunakan merupakan penelitian Research and Development (R\&D). Pengembangan LKS menggunakan model 4-D yang dimodifikasi menjadi model 3-D. Model ini terdiri dari 3 tahap yaitu: tahap pendefinisian (Define), perancangan (Design) dan pengembangan (Develop) tanpa mengikut sertakan penyebaran (Disseminate) dikarenakan keterbatasan waktu. Hasil penelitian berdasarkan analisis penilaian oleh ketiga ahli yaitu: ahli bahasa, ahli materi, dan ahli media menunjukkan bahwa LKS memenuhi kriteria valid dengan rata-rata skor 3,12. Sedangkan hasil analisis penilaian angket respon siswa diperoleh bahwa LKS memenuhi kriteria praktis dengan rata-rata skor 3,55 dan memiliki efek potensial yakni 27 siswa $(84,37 \%)$ yang nilainya mencapai ketuntasan belajar, sedangkan 5 orang siswa $(15,63 \%)$ belum mencapai ketuntasan belajar. Simpulan, pengembangan LKS mengggunakan Contextual Teaching and Learning (CTL) berbasis kota Lubuklinggau dinyatakan valid, praktis dan memiliki efek potensial ketuntasan belajar siswa.
\end{abstract}

Kata Kunci: Contextual Teaching and Learning, Lembar Kerja Siswa

\begin{abstract}
The purpose of this study was to develop student worksheets (LKS) using the Lubuklinggau city-based Contextual Teaching and Learning (CTL) on the set material in class VII according to the 2013 curriculum and find out the quality of worksheets developed from the validity, practicality and potential effects of using $L K S$. The research method used is Research and Development $(R \& D)$ research. Development of worksheets using a 4-D model that was modified to a 3-D model. This model consists of 3 stages, namely: the stage of defining (Define), design (Development) and development (Develop) without including the spread (Disseminate) due to time constraints. The results of the study are based on the assessment analysis by the three experts namely: linguists, material experts, and media experts showing that the worksheet fulfills valid criteria with an average score of 3.12. While the results of the analysis of student response questionnaire
\end{abstract}


assessments obtained that the student worksheets meet practical criteria with an average score of 3.55 and have a potential effect of 27 students (84.37\%) whose grades reach mastery learning, while 5 students (15.63\%) not reached mastery learning. In conclusion, the development of student worksheets using the contextual Teaching and Learning (CTL) based on the city of Lubuklinggau is declared valid, practical and has a potential effect on students' mastery learning.

Keywords: Contextual Teaching and Learning, Student Worksheet

\section{PENDAHULUAN}

Dalam proses pembelajaran, guru perlu membiasakan siswa memecahkan permasalahan sendiri dan menemukan hubungan materi yang dipelajari dengan kehidupan nyata sehingga pembelajaran menjadi lebih bermakna dan nyata. Siswa membangun sendiri pengetahuan mereka melalui keterlibatan aktif dalam proses pembelajaran (Thabany, 2014).

Bahan ajar yang digunakan oleh guru harus disesuaikan dengan kurikulum yang digunakan dan salah satu bahan ajar yang dapat membantu siswa untuk terlibat aktif dalam kegiatan pembelajaran yaitu lembar kerja siswa (LKS). Menurut Trianto (2009) LKS dapat digunakan sebagai latihan pengembangan aspek kognitif maupun panduan untuk mengembangkan semua aspek pembelajaran baik dalam bentuk eksperimen maupun demonstrasi. Menurut Soeyono (2014) LKS saat ini lebih difokuskan pada materi dan latian soal yang mengakibatkan pembelajaran yang dilakukan lebih bersifat teachercentered sehingga tidak memberikan kesempatan kepada siswa untuk membangun pengetahuannya sendiri.
Tentu saja hal tersebut membuat siswa terbiasa menggunakan sebagian kecil kemampuan analisis sehingga siswa menjadi malas berpikir mandiri.

Berdasarkan hasil observasi pada tanggal 25 Januari 2019 dengan salah satu guru mata pelajaran matematika di SMP Negeri 7 Lubuklinggau yaitu Noni, S. Pd diketahui bahwa guru belum mengembangkan LKS sebagai bahan mengajar dan menggunakan LKS yang siap pakai disusun oleh Dyah shofia Fitriani penerbit Calileo.

Kenyataannya LKS yang dipakai kurang menarik, tampilannya hanya berwarna pada bagian halaman depan sedangkan bagian isi tidak berwarna, bahasa yang bersifat abstrak sehingga siswa sulit memahami isi LKS, tidak memuat kegiatan-kegiatan siswa karena guru menggunakan LKS ketika akan memberikan soal latihan atau PR, lembar jawaban yang diberikan sangat sedikit sehingga siswa harus menjabarkan jawaban pada kertas lain dan tidak ada petunjuk mengerjakan LKS sehingga siswa kesulitan memahami 
isi dari LKS.

Selain itu berdasarkan hasil observasi, kurang aktifnya siswa diakibatkan oleh kurangnya pemahaman konsep siswa. Hal ini terlihat bahwa pembelajaran berpusat kepada guru. Guru menjelaskan materi pelajaran, kemudian memberikan contoh soal kepada siswa. Selanjutnya guru memberikan latihan kepada siswa dan meminta siswa menyelesaikan secara individu. Akan tetapi banyak siswa yang menyalin pekerjaan temannya.

Ini menunjukkan bahwa siswa belum paham konsep yang diberikan guru dan hanya menghafal konsep yang diberikan oleh guru. Kurangnya pemahaman siswa dapat terlihat dari ulangan harian matematika siswa kelas VII tahun 2018/2019. Sebanyak 130 siswa atau 48,33\% dari jumlah siswa kelas VII yang tuntas. Sisanya sebanyak 139 atau $51,67 \%$ belum tuntas. Dari hasil tersebut masih banyak siswa yang belum tuntas atau mencapai kriteria ketuntasan maksimal (KKM) sebesar 69,8.

Menurut Handayani \& Novianti (2018) dalam pelaksanaan kegiatan belajar mengajar selain menggunakan LKS, guru juga perlu menggunakan model pembelajaran yang tepat dan sesuai dengan tujuan pembelajaran, kondisi siswa dan kondisi tempat tinggal agar meningkatkan penyerapan dan penerimaan materi matematika. Guru diharapkan dapat memilih model pembelajaran yang mampu menimbulkan minat belajar, membantu guru mengaitkan materi yang dipelajari dengan situasi dunia nyata dan menunjang tumbuhnya pembelajaran yang berpusat pada siswa sehingga hasil belajar siswa dapat meningkat.

Salah satu model pembelajaran dapat memenuhi tuntutan tersebut adalah contextual teaching and learning (CTL). CTL bertujuan membantu guru mengaitkan antara materi yang diajarkan dengan situasi dunia nyata siswa dan mendorong siswa membuat kaitan antara pengetahuan yang dimiliki dengan penerapannya dalam kehidupan. Melalui model pembelajaran CTL, siswa bukan lagi penerima informasi atau fakta dengan menghapal sejumlah konsep tetapi dapat menemukan sendiri pengetahuan, konsep, teori dan kesimpulan. Dengan demikian, pembelajaran akan lebih bermakna (Rusman, 2010)

Agar LKS lebih menarik dan sesuai dengan karakteristik tempat tinggal siswa, maka seharusnya LKS menggunakan konteks kota Lubuklinggau. Dengan LKS yang menggunakan model pembelajaran CTL dipadukan konteks kota tempat tinggal seperti kota Lubuklinggau dapat digunakan sebagai ide dan konsep matematika sehingga LKS yang dibuat dapat menarik minat belajar siswa dan dekat dengan keseharian siswa.

Menurut Friansah (2018) suatu LKS dengan konteks kota 
Lubuklinggau melalui pembelajaran matematika diharapkan nantinya siswa dapat lebih memahami matematika dan lebih memahami budaya yang ada di sekitarnya sehingga dapat menarik minat belajar siswa dalam mempelajari matematika. Hal ini sejalan dengan pendapat Refianti \& Idul (2019) bahwa penggunaan konteks yang disesuaikan dengan lingkungan siswa dapat mempermudah siswa memahami suatu permasalahan matematika yang disajikan.

Salah satu materi pelajaran yang dapat memberi makna melalui pengalaman belajar siswa adalah himpunan. Materi tersebut berkaitan dengan kehidupan sehari-hari. Himpunan merupakan materi yang termuat dalam kompetensi dasar mata pelajaran matematika SMP Negeri 7 Lubuklinggau di kelas VII yang harus dicapai oleh siswa melalui pengalaman belajar. Pembelajaran mengenai himpunan sebaiknya diawali dengan menghadirkan permasalahan nyata untuk memberikan stimulus kepada siswa agar siswa mampu berpikir kreatif dan dapat menemukan sendiri solusi dari masalah yang dihadapi.

Penelitian ini menekankan pada pengembangan lembar kerja siswa (LKS) mengggunakan Contextual Teaching and Learning (CTL) berbasis kota Lubuklinggau pada materi himpunan dan mengetahui kualitas LKS yang dikembangkan dari aspek kevalidan, kepraktisan dan efek potensial penggunaan LKS

\section{METODE PENELITIAN}

Metode penelitian yang digunakan dalam penelitian ini adalah metode Research and Development (R\&D). Menurut Sugiyono (2015) metode penelitian dan pengembangan (Research and Development) merupakan cara ilmiah untuk meneliti, merancang, memproduksi dan menguji validitas produk yang telah dihasilkan.

Penelitian ini menghasilkan produk bahan ajar berupa lembar kerja siswa (LKS) menggunakan contextual teaching and learning (CTL) berbasis kota Lubuklinggau pada materi himpunan di kelas VII.

Desain dan pengembangan LKS menggunakan model pengembangan 4-D yang terdiri atas 4 tahapan yaitu Define (tahap pendefinisian), Design (tahap perancangan), Develop (tahap pengembangan) dan Disseminate (tahap penyebaran). Namun pengembang memodifikasi model 4-D tersebut menjadi model 3D, sehingga Disseminate (tahap penyebaran) tidak dilakukan oleh pengembang karena keterbatasan tenaga dan biaya.

\section{Langkah-langkah Pengembangan Model}

Pengembangan LKS yang digunakan dalam penelitian ini adalah pengembangan yang menggunakan perangkat model 4D, namun karena keterbatasan waktu penelitian maka model ini dimodifikasi menjadi 3-D seperti diuriaikan pada bagan 1 dibawah ini. 


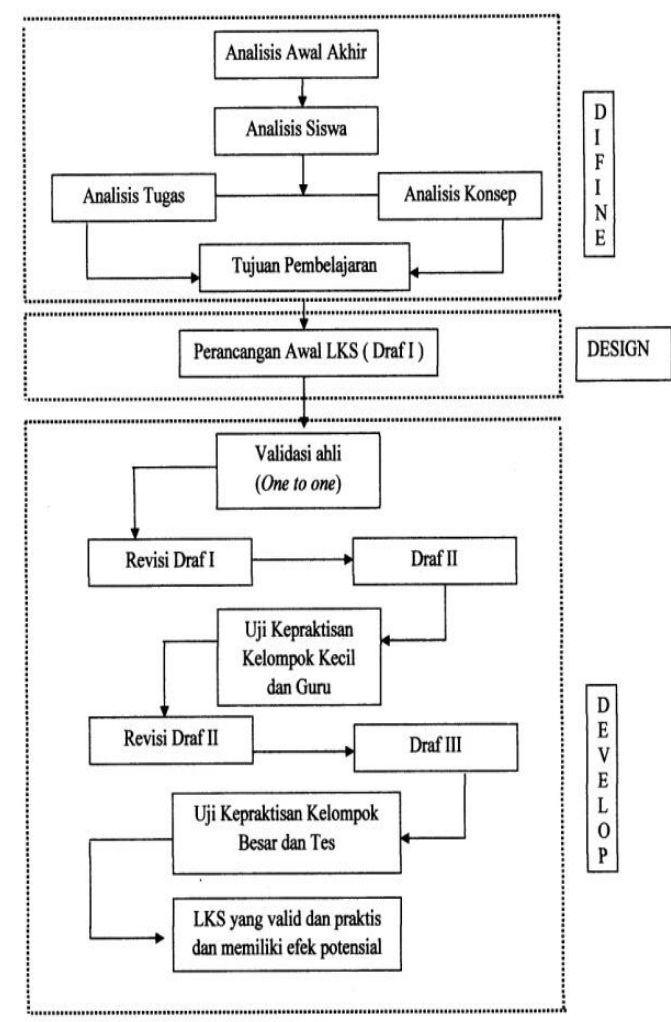

Bagan 1. Model 4D dimodifikasi menjadi 3-D

\section{Tahap Define}

Tahap pendefinisian adalah tahap awal untuk melakukan pengembangan. Tahap ini meliputi beberapa langkah, diantaranya: a) Analisis awal akhir, b) Analisis siswa, c) Analisis tugas, d) Analisis konsep, dan e) Perumusan tujuan pembelajaran.

\section{Tahap Design}

Tahap perancangan mempunyai tujuan untuk menghasilkan draf LKS. Ada beberapa langkah pada tahap ini, yaitu sebagai berikut: penyusunan tes, acuan patokan, pemilihan media, pemilihan format dan desain awal LKS

\section{Tahap Development}

Tahap ini terdiri dari pengembangan LKS, validasi, dan revisi LKS. Tahap pengembangan ini bertujuan untuk menghasilkan lembar kerja siswa (LKS) menggunakan contextual teaching and learning (CTL) berbasis kota Lubuklinggu pada materi himpunan di kelas VII yang sudah divalidasi dan direvisi berdasarkan masukan para validator dan hasil uji kepraktisan oleh 2 guru dan 6 siswa kelas.

Subyek penelitian terdiri dari ahli atau pakar, siswa SMP Negeri 7 Lubuklinggau kelas VII.2 untuk uji perorangan dan uji coba kelompok kecil. Dan siswa VII.1 untuk uji coba kelompok besar. Instrumen penelitian berupa angket untuk siswa dan pakar yang selanjutnya dianalisis. Angket ahli digunakan untuk mengetahui sejauh mana kevalitan LKS yang dikembangkan. Angket ahli diberikan kepada ahli bahasa, ahli materi dan ahli media. Penilaian lembar validasi menggunakan skala likert sesuai dengan tabel di bawah ini yang diadaptasi dari Sugiyono (2015).

Tabel 1.

Pedoman Penilaian Lembar Validasi LKS

\begin{tabular}{cc}
\hline Nilai & Kriteria \\
\hline 4 & Sangat baik \\
\hline 3 & Baik \\
\hline 2 & Tidak baik \\
\hline 1 & Sangat tidak baik \\
\hline
\end{tabular}

Langkah berikutnya adalah menghitung rata-rata nilai validasi ahli dan mengubah skor rata-rata seluruh aspek menjadi nilai 
kualitatif sesuai dengan kriteria penilaian validitas yang diadaptasi Yuliana (2017).

Tabel 2.

Kriteria Tingkat Kevalidan

\begin{tabular}{cc}
\hline Nilai & Kriteria \\
\hline$V>3,4$ & Sangat valid \\
\hline $2,8 \leq V \leq 3,4$ & Valid \\
\hline $2,2 \leq V \leq 2,8$ & Cukup valid \\
\hline $1,6 \leq V \leq 2,2$ & Kurang valid \\
\hline$V \leq 1,6$ & Sangat kurang valid \\
\hline
\end{tabular}

Pemberian angket siswa bertujuan untuk mengetahui sejauh mana kepraktisan LKS yang dikembangkan. Sedangkan tes hasil belajar dilakukan untuk melihat kemampuan siswa dalam menyelesaikan soal-soal yang terdapat pada LKS. Tes hasil belajar digunakan untuk mengetahui apakah LKS yang dikembangkan memiliki efek potensial terhadap hasil belajar siswa. Analisis data tes ini menggunakan analisis data deskriptif dengan mencari rata-ratanya. Hasil dari rata-rata nilai siswa dikonversikan ke dalam bentuk data kualitatif untuk mengetahui hasil belajar siswa.

\section{HASIL PENELITIAN}

Berdasarkan hasil penelitian yang telah dilakukan diperoleh informasi berupa :

\section{Bahan Ajar yang Valid dan Praktis}

Setelah melalui uji coba kelompok kecil, uji coba kelompok besar dan uji validasi oleh pakar diperoleh Lembar kerja Siswa (LKS) Menggunakan contextual teaching and learning (CTL) berbasis kota Lubuklinggau yang valid dan praktis.
Valid tergambar dari hasil penilaian validator, dimana semua validator menyatakan baik Praktis tergambar dari hasil uji coba lapangan dimana rata-rata siswa menyelesaikan permasalahan LKS dengan baik.

\section{Memiliki Efek Potensial}

Salah satu tujuan uji coba kelompok besar adalah untuk mengetahui efek potensial LKS yang dikembangkan. Efek potensial dapat dilihat dari aktivitas siswa dalam mengerjakan soal pada LKS, dimana siswa akan lebih mudah memahami konsep matematika yang terdapat pada LKS serta menggunakan konsep tersebut secara tepat dalam menyelesaikan persoalan yang diberikan. Data hasil latihan tes kemampuan siswa dianalisis untuk menentukan nilai akhir dan kemudian dikonversikan ke dalam data kualitatif untuk menentukan kategori tingkat kemampuan siswa seperti pada tabel berikut.

Tabel 3.

Pedoman Ketuntasan

Hasil Belajar Siswa

\begin{tabular}{ccc}
\hline Nilai & $\begin{array}{c}\text { Rentang } \\
\text { Nilai }\end{array}$ & Kategori \\
\hline A & $89-100$ & Tuntas \\
\hline B & $77-88$ & Tuntas \\
\hline C & $69,8-76$ & Tuntas \\
\hline D & $<69,8$ & Tidak tuntas \\
\hline
\end{tabular}

\section{PEMBAHASAN}

Berdasarkan hasil analisis penilaian kevalidan LKS oleh para ahli mendapatkan skor rata-rata 
3,12 yang dikatagorikan valid dan layak untuk diuji cobakan dengan beberapa perbaikan sesuai saran dari ketiga ahli. Setelah LKS direvisi selanjutnya diuji cobakan pada guru dan kelompok kecil yang terdiri dari 6 siswa kelas VII.2 SMP Negeri 7 Lubuklinggau dan kelompok besar kelas VII.1 untuk mengetahui kepraktisan LKS yang dikembangkan. Penilaian kepraktisan yang dilakukan oleh guru melalui lembar kerpaktisan yang terdiri dari 11 pernyataan diperoleh rata-rata skor sebesar 3,56 dengan kriteria sangat praktis.

Pada tahap uji coba kelompok kecil yang terdiri dari 6 siswa hasil analisis data lembar kepraktisan siswa sebanyak 11 pernyataan dengan ratarata skor sebesar 3,16 dengan kriteria praktis. Pada tahap uji coba kelompok besar yang terdiri dari 32 siswa hasil analisis data lembar kepraktisan siswa sebanyak 11 pernyataan dengan ratarata skor sebesar 3,34 dengan kriteria praktis.Sehingga dapat disimpulkan rata-rata skor kepraktisan yang dinilai oleh siswa dan guru SMP Negeri 1 Lubuklinggau adalah 3,35 dengan kriteria praktis.

Uji coba LKS kepada siswa kelas VII.1 SMP Negeri 7 Lubuklinggau yang berjumlah 32 siswa. Pada tahap ini peneliti ingin efek potensial yang diperoleh dari penggunaan LKS. Dari analisis hasil belajar diperoleh 27 siswa $(84,37 \%)$ yang nilainya mencapai KKM. Sedangkan 5 orang siswa $(15,63 \%)$ belum mencapai KKM.

\section{SIMPULAN}

Pengembangan

LKS mengggunakan Contextual Teaching and Learning (CTL) berbasis kota Lubuklinggau dinyatakan valid, praktis dan memiliki efek potensial ketuntasan belajar siswa.

\section{DAFTAR PUSTAKA}

Friansah. (2018). Desain Lembar Kerja Siswa Materi Sistem Persamaan Dua Variabel Berorientasi Etnomatematika. Jurnal Pendidikan Matematika : Judika Education, 1(2), 83-92. Handayani \& Novianti. (2018). Pengembangan Lembar Kerja Siswa (LKS) Berbasis Problem Based Learning Untuk Meningkatkan Kemampuan Penalaran Matematika. Jurnal Pendidikan Matematika : Judika Education, 1(2), 144-151.

Refianti \& Idul. (2019). Pengembangan Lembar Kerja Siswa (Lks) Menggunakan Pendekatan Matematika Realistik Indonesia Berbasis Konteks Sumatera Selatan. Jurnal Pendidikan Matematika : Judika Education, 1(2), 1-10.

Rusman. (2010). Model-model Pembelajaran. Jakarta: PT. Rajagrafindo Persada.

Soeyono. (2014). Pengembangan

Bahan Ajar Matematika dengan Pendekatan OpenEnded untuk meningkatkan kemapuan berpikir kritis dan kreatif Siswa SMA. Pythagoras Jurnal Pendidikan Matematika, 9 (2), 205-218.

Sugiyono. (2015). Metode Penelitian \& Pengembangan: 
Research

and

Development.Bandung: Alfabeta.

Tabany. (2014). Mendesaian Model Pembelajaran Inovatif, Progresif dan Kontekstual. Jakarta: Prenadamedia Grup.

Trianto. (2009). Mendesain model pembelajaran inovatif-Progresif. Jakarta: Kencana Prenada Media Group.

Zaini. (2015). Karakteristik Kurikulum 2013 dan Kurikulum Tingkat Satuan Pendidikan (KTSP). Jurnal idaroh, 1 (1), 15 - 31.

Friansyah, D., \& Luthfiana, M. (2018). Desain Lembar Kerja Siswa Materi Sistem Persamaan Dua Variabel Berorientasi Etnomatematika. Jurnal Pendidikan Matematika : Judika Education), 1(2), 83-92. https://doi.org/https://doi.org/10.3 1539/judika.v1i2.322

Refianti, R., \& Adha, I. (2019). Pengembangan Lembar Kerja Siswa (LKS) Menggunakan Pendekatan Matematika Realistik Indonesia Berbasis Konteks Sumatera Selatan. Jurnal Pendidikan Matematika (Judika Education), 2 (1); 1-10.

Handayani, S., \& Mandasari, N. (2018). Pengembangan Lembar Kerja Siswa (LKS) Berbasis Problem Based Learning untuk Meningkatkan Kemampuan Penalaran Matematika. Jurnal Pendidikan Matematika : Judika Education, 1(2), 144-151. https://doi.org/https://doi.org/10.3 1539/judika.v1i2.412 